\title{
The plough in the pictorial sources of Ancient Mesopotamia
}

\author{
Dalia Hanafy \\ Associate Professor at the Department of history - Faculty of Arts - \\ Mansoura University
}

\section{Introduction:}

In ancient Mesopotamian the plough was one of the most important tools of agriculture, it was used for cutting furrows in the soil, and especially to prepare for the planning of the seed in addition the plough was connected with a number of gods and symbols of gods. The plough in Akkadian language was identified as agadibbu (Sumerian gišs. apin. lú. gíd. da, giš. apin. zu. zu and giš. apin. zu) it means a hand seeder-plough (Black et al, 2000: 5; CAD A 1, P. 139) and ingu (Sumerian giš.u $u_{5}$.apin, giš. $u_{5}$. GAB. apin, giš. $u_{5}$ ) and it means the top part of the plough (MSL 6, 19, 169; AHW 382; CAD I-J, P. 147).

Complete ploughs were not found except for wooden parts. The wooden parts of it were moldered or reused in another industry. The plough was plenty depicted in the arts of ancient Mesopotamian especially on seals and boundary stones or kudurru. Ploughs dated to the First Millennium B.C were found in Hursbad, Zinjirli, Bogazkoy and Palestine, such ploughs consist of an iron tapered plate with three corners (Vétersalji, 1983: 15f), a same plough was represented on a seal from the Old Akkadian Period (Fig. 1) (EGA Abb. 715a).

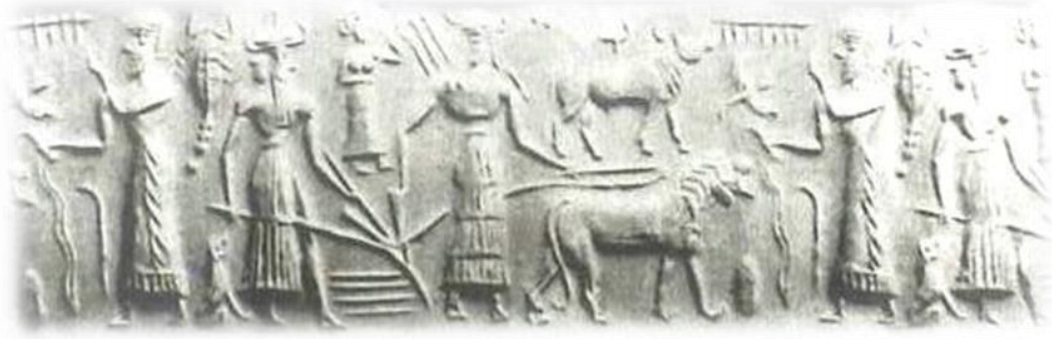

Fig. 1 a plough pulled by lions- early dynastic period

\section{EGA 715a}

Ploughs from daily life were represented on the seals of the Early Period. A seal from tell Sulayma represented a plough and three men, the first man is holding the bridle of two oxen with his right hand and with his left one is holding a stick. The second man is sowing the grain from a funnel; the third man is holding the plough itself (Boehmer, 1965: Abb.711). Such ploughs with three men were commonly used during the Old Akkadian period till the Kassite period.

In the religious and legendary scene ploughs were depicted on seals from the early dynastic period till the Akkadian period (Fig. 2) (Heinrich, 1931: Taf. 58), some of those ploughs were pulled by lions (fig. 3). 


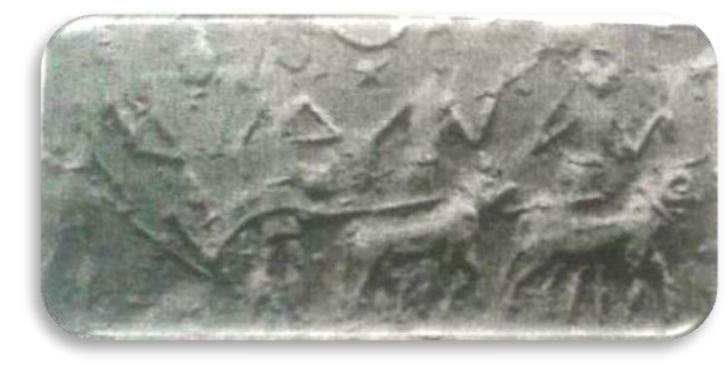

Fig. 2: plough pulled by lions - early dynastic period EGA Abb. 711; Heinrich, 1931: Taf. 58

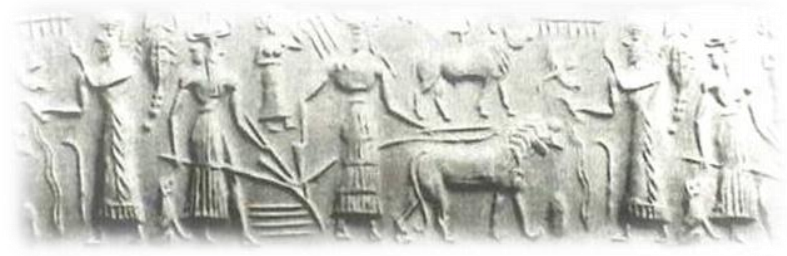

Fig.3 a plough pulled by lions- early dynastic period EGA 715a

From Fara ploughs were represented on seals pulled by an ox with a human face (Fig. 4 ) (Heinrich, 1931: Taf. 58)

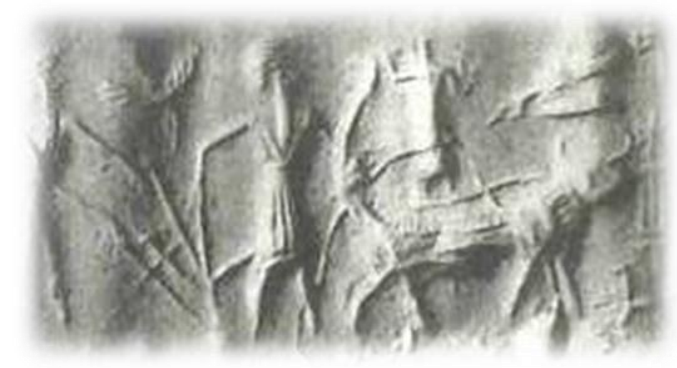

Fig. 4 plough pulled by an Ox with a human face - Fara period Heinrich, 1931: Taf. 58; EGA 715

or by a god in a form of a man sometimes this god was a male or female. A scorpion was always depicted in the scene of the plough but the connection between the scorpion and the plough is obscure (Fig. 5).

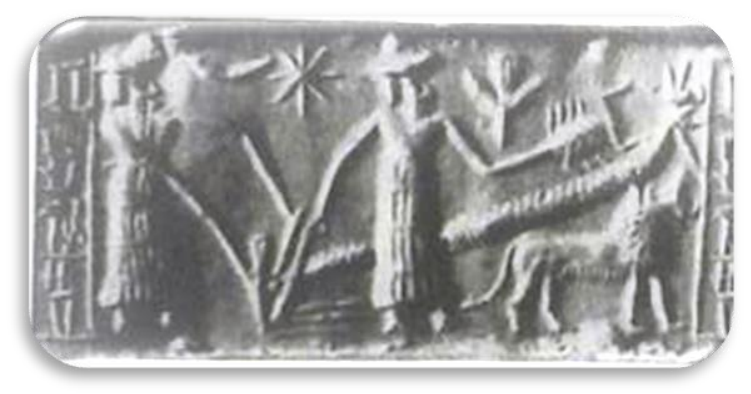

Fig.5 plough pulled by a god - cylinder seal - Fara Period EGA Abb. 714 
From the early Sumerian Period ploughs were depicted in connection with lions with human face or in connection with an eagle with a human face. The eagle with a human face was the god Anzu the symbol of the god Ningirsu the main god of Lagash and that refers to the connection of the plough to the god Ningirsu.

From the Middle Assyrian period and the New Assyrian Period simple ploughs were represented pulled by only one ox and in the scene only one man was represented (Moortgat, 1941: 81), the man is holding the bridle with his right hand and with the other hand is holding the plough (Lambert, 1979: 22, Fig. VII Nº 63; CANES $1 \mathrm{~N}^{\circ}$. 653).

\section{The plough as symbol of gods:}

\section{1-The plough as symbol of the sun god Šamaš:}

On a seal from the Akkadian period the god Šamaš was depicted seating on a throne in a ship in a form of dragon, the god Šamaš is holding a paddle with his right hand and a plough with his left one (Fig. 6).

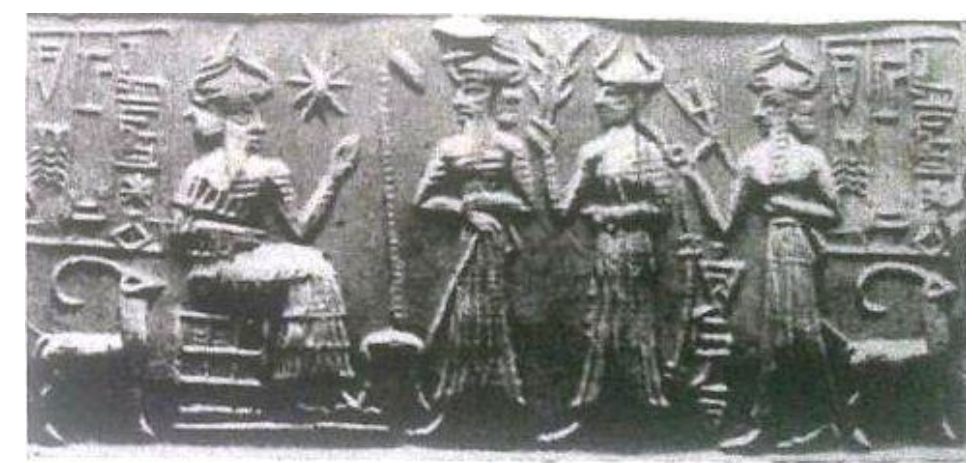

Fig. 6 The god Assur holding a plough - Akkadian Period

GAG Abb. 615

On another seal from the same period the son god Šamaš was depicted in a ship seating on a throne without arms holding two paddles in his hands. The dragon ship is navigating by a secondary god holding a paddle in his right hand and pulls an animal with his left one. Vessels with different size were depicted and upon it a plough the symbol of the god Šamaš was depicted. In my opinion the connection between the god Šamaš and the plough refers to one of his important function as a god of the fertile cultivated lands. In the Akkadian Period the god Šamaš was described as the shepherd and the farmer and the one who caused the growth of the grain and greenery.

\section{The plough on the Kudurru (Boundary steale):}

\section{Louvre museum Nr. SB 783}

The plough was represented on a boundary stale from the end of the Kassite Period from Susa, preserved in Louvre museum Nr. SB 783, limestone, H. $23 \mathrm{~cm}$ and W. $13 \mathrm{~cm}$ (Seidel, 1989: N. 36; Contenau, 1943: 136).

The plough was depicted accompanied by the text: DINGIR.NIN.GÍR.SU "the god Ningirsu" (Fig. 7), the main god of the city state Lagash, a double mace headed was also represented (Scheil, 1937: 42). The double mace headed was the symbol of the god Ningirsu or the god Ninurta, with no doubt, the double headed mace refers to Ningirsu as the god of war and the plough refers to him as a god of fertility. We can easily compare the scenes of the double headed mace and the plough on the kudurru with the scene 
from the early dynastic period especially on the seals, when a plough, vessels and a lion with a head of a man were depicted together as a symbol of the Ningirsu (Seidel, 1989: 127), moreover with the scenes on another seals, when a plough and a vulture with a head of lion where depicted. The vulture with a head of lion was the god Anzu, the symbol of the god Ninngirsu (Seidel, 1989: 127). Such symbols refer to the double function of the God Ningirsu as a god of war one side and a god of fertility on the other side.

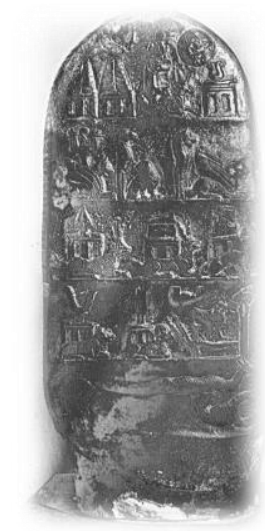

Fig. 7 Boundary stone- Susa- Louvre Museum

\section{BKR Taf. 15g}

\section{Boundary stone Louvre Museum Nr. SB 22}

The plough was also depicted on a kudurru from Susa, preserved in Louvre Museum Nr. SB 22, made of limestone, H. $86 \mathrm{~cm}$, W. $19 \mathrm{~cm}$ (Seidel, 1989: $\mathrm{N}^{\mathrm{O}} .32$ ). The Kudurru is a square stone; its high edge is circle (De Morgan, 1900: 127; Scheil, 1900: 99f). The symbols were represented on only one side in five registers. The other three sides of the Kudurru bear writing from the time of the king Meli-ši.Hu. The plough on this kudurru represented the symbol of the god Ninurta/Ningirsu and refers here to his double function one side as a god of war and on the other side as a god of cultivation and fertility (Fig. 8).

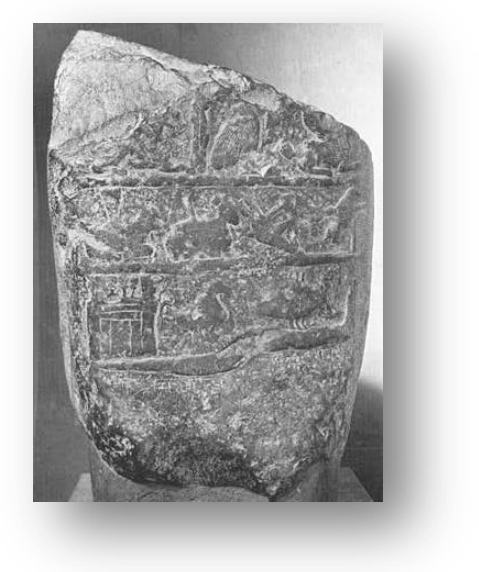

Fig. 8 Boundary stone- Susa- Louvre Museum

BKR Taf. 15 c (Nr. 33)

Boundary stone Louvre Museum Nr. SB 32 
Publication and translation: V. Scheil, MDP VI (1905) P. 44 ff; F. X. Steinmetzer, Or 5 (1936) $347 f$.

On another kudurru from Susa, preserved in Louvre Museum Nr. SB 32, made of black limestone, H. $45 \mathrm{~cm}$, W. $30 \mathrm{~cm}$ (Seidel, 1989: $\mathrm{N}^{\mathrm{o}}$. 33), this kudurru is irregular stone has only three side. Only the remaining part of the kudurru is the bottom (De Morgan, 1905: 145, Abb. 456). The symbols of the gods covered only one side of the kudurru. A plough was depicted (Scheil, 1905: 44; Steinmetzer, 1936: 347f) as a symbol of the god Ningirsu as a god of cultivation and fertility (Fig. 9).

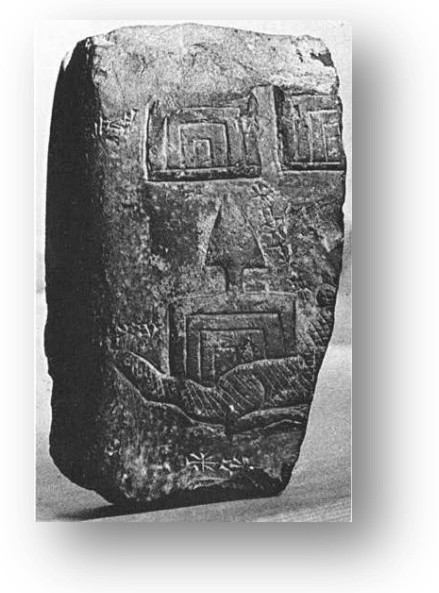

Fig. 9 Boundary stone from Susa - Louvre Museum

BKR Taf. 16 a

Boundry stone: Louvre Museum Nr. SB 6435

Publication: F. Thureau-Dangin, Ibid., 135f.

On a fragment of a kudurru from Susa, preserved in Louvre Museum Nr. SB 6435, made of black limestone, H. $8,3 \mathrm{~cm}$, W. $9,5 \mathrm{~cm}$, a plough was depicted accompanied with Akkadian writing (Seidel, 1989: N$^{\mathrm{o}} .34$ ) (Fig. 10).

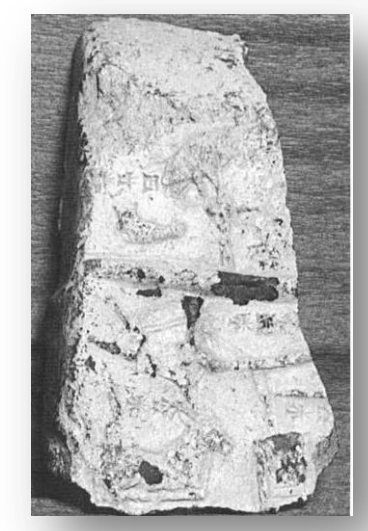

Fig. 10 Boundary stone from Susa- Louvre Museum

BKR Taf. 16c 
A fragment of a boundary stone Louvre Museum Nr. SB 35

Description: J. De |Morgen, MDP VII (1905) 146.

Photo: Ibid., Abb. 457

Publication: Ibid.; V. Scheil, MDP VI (1905) 47

On a fragment of a kudurru from Susa, preserved in Louvre Museum Nr. SB 35, made of dark limestone (Scheil, 1905: 146). On one side a rest of text and on the other side a destroyed relief and a rest of a text (De Morgen, 1905: 146). A plough was depicted as a symbol of the god Ninurta/Ningirsu as a god of fertility (Fig. 11).

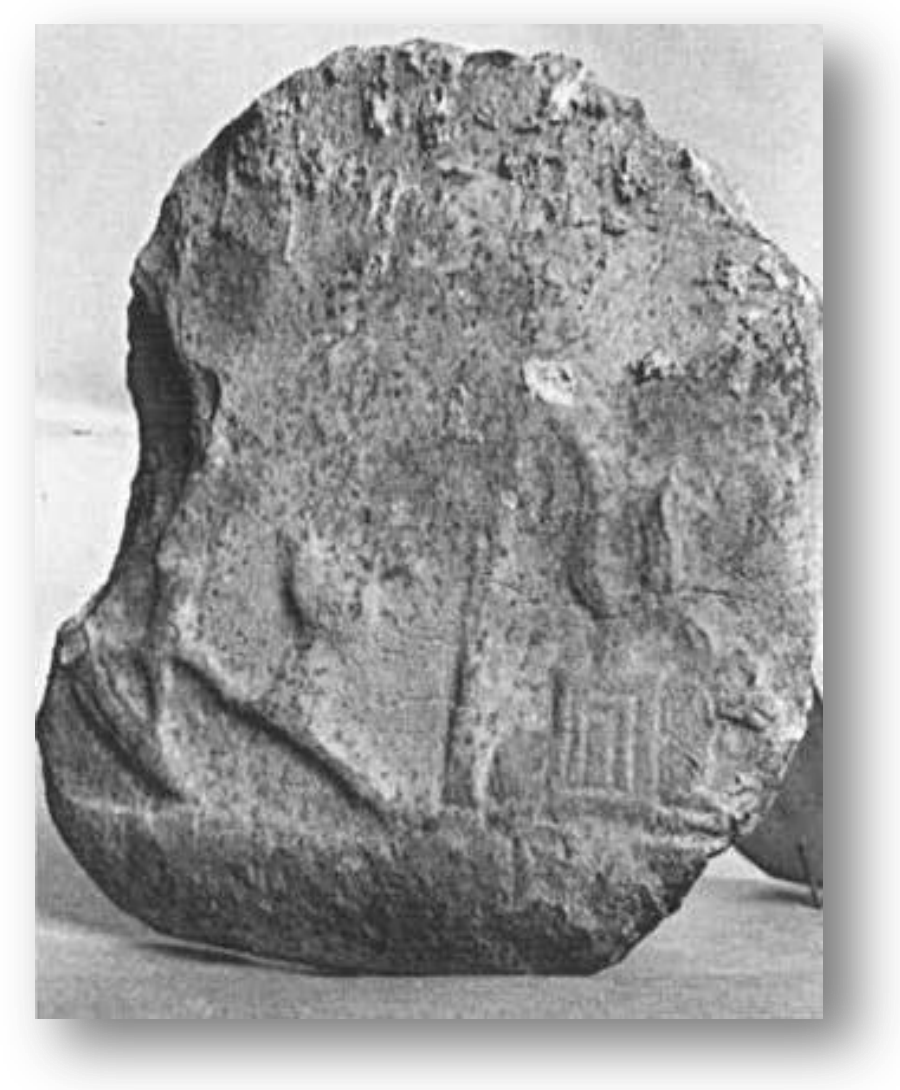

Fig. 11 Boundary stone from Susa - Louvre museum

BKR taf. 16b

A fragment of a boundary stone Louvre Museum Nr. SB 35

Description: G. Contenau, MDP XXIX (1943) 170

On a fragment of a kudurru from Susa, preserved in Louvre Museum Nr. SB 35, made of dark limestone, H. $17 \mathrm{~cm}$, W. $17 \mathrm{~cm}$ a plough was represented (Contenau, 1943: 170).

The plough appeared in the reliefs of an architrave from the temple of the god Sin, the moon god, in Khorsbad from the New Assyrian Period; many other symbols were depicted such as a vulture, ox and figs tree. The plough and the vulture are surely the symbols of the god Ninurta/ Ningirsu with his double function as a god of war one side and a god of fertility on the other side, the vulture (here represented the god Anzu) is his symbol as a war god, and the plough is his symbol as a cultivation and fertility god. 
On basalt memorial stone dated to the time of the Assyrian King Assur-aha-iddin (Assurhadon) from Kujundjik a plough was depicted between a pile of grain (?), a palm tree and shovel (Fig 12).

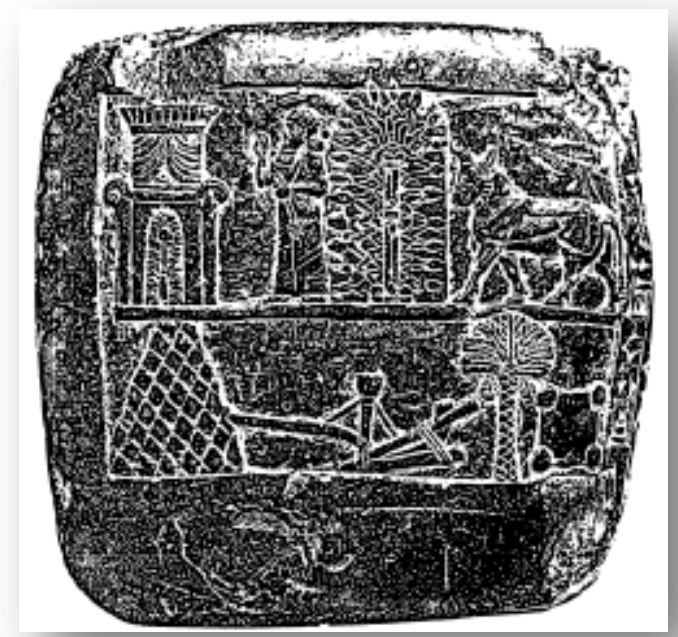

\section{Conclusion:}

\section{Fig. 12 Memorial stone - Assur Ahadin - Basalt- British Museum}

The plough was one of agriculture tools in ancient Mesopotamian. It was used to plough the ground. The plough in Ancient Mesopotamia consisted of two parts, a wooden part and a metal part. The plough was depicted multiply on seals from the early Sumerian period till the middle Assyrian period, as far as on boundary stone from the Kassite period and on the walls of the palaces from the New Assyrian period. Moreover the plough was depicted in the daily life scene and in the religious context. In ancient Iraq the plough was symbol of various gods such as the god Ningirsu/ Ninurta but in this case as fertility god not god of war, moreover as the symbol of the god Assur, the god of agriculture, other side as a symbol of the goddess Gestinnan the goddess of agriculture 


\section{References:}

Black, J. et al, (2000) A concise dictionary of Akkadian, Wiesbaden.

Boehmer, R. M. (1965) Die Entwicklung der Glyptik während der Akkad -Zeit, Untersuchungen zur Assyriologie und Vorderasiatischen Archäologie, Berlin.

Boehmer, R. M. (1972) Die Kleinfunde von Bogazköy, Ergebnisse der Ausgrabungen des Deutschen Archäeologischen Institus und der Deutschen Orient-Gesellschaft, Wissenschsftliche Veröffentlichung der Deutschen Orient-Gesellschaft 87.

Curtis, J. (1999) Late Assyrian agricultural tools: the archaeological evidence, BBVO 18.

Douglas Van Buren, E. (1945) Symbols of Gods in Mesopotamian Art, AnOr 23.

Lambert, W. G. (1979), "Near Eastern seals in the Gulbenkian Museum of Oriental Art, University of Durham", Iraq 41/No. 1, PP. 1-45.

Moortgat, A. (1940) Vorderasiatische Rollsiegel, ein Beitrag zur Geschichte der Steinschneidkunst, Berlin.

Parrot, A. (1954) Glyptique Mésopotamienne, Fouilles de Lagash (Tello) et de Larsa (Senkereh) (1931-1933), Paris.

Scheil, V. (1900) Mémoires, tome II: Textes élamites-sémitiques, Délégation en perse, Paris.

Scheil, V. (1937)"La charrue symbole de Ningirsu", RA 34.

Seidel, U. (1989) Die babylonischen Kudurru-reliefs: symbole mesopotamischer Gottheiten, Orbis Biblicus et Orientales 87, Freiburg \& Göttingen.

Steinmetzer, F. X. (1922) Die babylonischen Kudurru (Grenzstein) als Urkunden Form, Paderborn.

Unger, E. (1927) Assyrische und Babylonische Kunst, Breslau.

Vétersalji, P. P. (1983) "Zu den Ackerbaugeräten der alten Mesopotamia", MDOG 115.

Warkte, R. B. (1982) Zur Rolle eiserner Landwirtcher Geräte des alten Orients aus der ersten Hälfte des 1. Jahrtausend V. . U. Z, in: (Hsg.) Herrmann, J. \& Sellnow, Produktivekräfte und Gesellschaftsformationen in vorkapitalistischer Zeit. 